\title{
Food Security and Sustainable Agriculture: A Case of Hungary
}

\author{
Ola Al Jaafreh ${ }^{1}$, Imre Nagy ${ }^{1,2}$ \\ ${ }^{1}$ Faculty of Economic Sciences, Kaposvár University, Hungary \\ ${ }^{2}$ Faculty of Sciences, University of Novi Sad, Serbia
}

Received date: 12 December 2019, Accepted date: 25 February 2020, Online date: 2 April 2020

\author{
Address for Correspondence: \\ Ola Al Jaafreh, Faculty of Economic Sciences, Kaposvár University, Hungary \\ E-mail: ola.aljaafreh2016@gmail.com
}

Copyright (C) 2020 by authors and American-Eurasian Network for Scientific Information This work is licensed under the Creative Commons Attribution International License (CC BY). http://creativecommons.org/licenses/by/4.0/

\section{(c) (i) Open Access}

\begin{abstract}
Sustainable agriculture plays a vital role in the economies of both under-developed and developed countries. This role is more vital for agricultural countries. The first task is to achieve a state of food security for all the population through sustainable agriculture. Sustainable agriculture includes the investment of available natural resources, the employment of all potential opportunities for the rural population, and agricultural raw materials to increase agricultural exports in order to reduce the balance of payments deficit. The purpose of the study is to examine the relationship between selected variables that shared between sustainable agriculture by its indicators and food security by its determinants in Hungary in the long term, the descriptive analysis. This study was based on data collection and information that helps to accurately describe the problem and analyze it, will be used to deliver accurate results. The historical approach will be used to identify and analyze the reasons for the relationships among the variables, as well as the study of their direction and growth; the collected data was subjected for analysis by using Gretl program (version, 2017). Results were summarised cointegration relations to examine the relationship between the variables, using VAR model, the study analyzed the dynamic relationship between Macroeconomic variables which have been chosen to be the link between sustainable agriculture and food security by the selection of some indicators of sustainable agriculture (Emission gas Greenhouse, Fertilizers consumption, Organic Farming, Agriculture Area).
\end{abstract}

\section{KEYWORDS}

sustainable development, sustainable agriculture, food security

\section{INTRODUCTION}

Sustainable agriculture plays an important role to enhance food security and nutrition by increasing the quality and diversity of the food. It is considered an engine of economic transformation, added to the fact that agriculture is the major source of income [8] for the majority of the population living in agricultural and agricultural areas. Sufficient income from agriculture is considered essential for all those working in agriculture because it is the one that directly secures their food requirements [16].

Sustainability is considered to be an essential part of long term food security assessment dimensions, in order to reach the nutritional well-being, also affected by policies and programmes representing sustainability to increase food security in the future[27] [6]. Ultimately, food security gradually and consistently enlarged to involve not only the food availability and food production but also its expansion to ensure explicitly and accessibility of food, simultaneously, live up to the present challenges without compromising the renewable resources and the continuity for future generation's sustainable development. Intensive experiences in different countries over many years indicate that agricultural development and economic growth are both necessary for the improvement of food security and nutrition. Also, sustainable agriculture can promote economic growth[17], 
pressure on food demand is because of the rising population, an increase of stagnation in global crop production, environmental pollution. To meet more and more of a sustainable future food system needs a strategy in intensifying agricultural production and the extensification of the agricultural areas, which holds risk and opportunities. The integration of extensification, intensification, and decreasing food dissipation and changing diets with fewer animal products have significant advantages for the environment and human health [15].

Nevertheless, The issues facing sustainability and agricultural development are particularly complex [32]; what is needed for the most pressing matters is an integrated and long-term vision. Furthermore, This means examining thoroughly the dynamics of the agriculture sector, which necessitates the existence of a very comprehensive vision of the agricultural sector, including its relevance to overall economic development, natural resources, demographic, social issues, cultural issues, and all other trends that are influencing these sections in the long term. As a next step, the interactions between the three dimensions of sustainability (environmental, economic and social) should be secured, harmonized, and strengthened for future generation transitions. Therefore, it is essential to identify the pathways to minimize the adverse environmental, economic and social impacts of livestock and vegetation to promote beneficial impacts [38]. Based on the early mentioned, the plant production and livestock sectors could serve as a miniature model for the broader agriculture sector to find the possible pathways for sustainable agricultural development for access to food security and nutrition [30]. The recommendations of food security and revealed determinants are the first responsible for food development and land policies and recommendations[25]. The purpose of the study is to examine the relationship between selected variables that shared between sustainable agriculture by its indicators and food security by its determinants in Hungary in the long term. Study the relationship and effect between variables conclude to effect of sustainable agriculture on food security. The variables used in the study were chosen based on their impact on sustainable agriculture and/or food security.

\section{2-Definition and differences between Economic Growth and Economic Development}

Most of the proponents of economic theories consider the economic development as a method that creates economic, social, quantitative, and qualitative changes, which in turn would make the national economy to raise its real national commodities in an aggregate and durable manner [37].

Indifference and in comparing with development, economic growth holds a limited meaning, an increase of the national income per capita, including the analysis, and especially in quantitative terms, of this method with emphasis on the functional relations through the endogenous variables; through a wider lens, it involves increasing the GDP, GNP, and NI [7]. Therefore, it is the national wealth, including the production capacity, expressed in both absolute and relative size, per capita, while also involving the structural modifications of the economy.

Economic growth is the way of improving the sizes of domestic economies, the macroeconomic indications, especially the GDP per capita, with a rising but not necessarily linear orientation. Additionally, leading to positive influences on the economic-social sector, while development illustrates how growth affects society by increasing the level of life [3].

\section{3-Definition of Sustainable Agriculture}

Sustainable agriculture is more than a specific methodology, and it is a wide-ranging concept. It includes both the advancements in agricultural management technology and practices [31], and the growing recognition specifies that the conventional agriculture that was developed post World War-II would not be able to meet the needs of the growing population at the 21st Century [33], Studies of [20][40] categorized the definitions of the sustainable agriculture into four groups. The First group emphasizes on the maintenance of human welfare to make a situation for the future generation that it will not be worse than the present. The second group agrees on only emphasizing on the survival of the human race. The third group agrees with the concept of flexibility of the production system. The fourth group is of the noneconomic notion, which is the significant role in preserving the cultural heritage, societies, and maintain diversity through the ecological system.

In sustainable agriculture, the focusing on methods and processes that are enhancing soil productivity while reducing the harmful effects on the environment, climate, soil, water, air, biodiversity [11] and human health, aims to reduce the use of inputs from nonrenewable sources and petroleum-based products, then attempting their replacement with those from renewable and clean resources, furthermore, to focus on local and domestic people and their needs, knowledge, awareness, skills, institutional structures and socio-cultural values.

Sustainable agriculture ensures that the basic nutritional requirements of present and future generations are and will be met, in both quality and quantity terms, providing long-term employment, a sufficient income, dignified and equal working, excellent opportunities and living conditions for everyone involved in the agricultural chains of value [42]. Ultimately, it lessens the agricultural sector's vulnerability in order to reverse natural conditions, climatic changes, and socioeconomic factors such as strong price fluctuations and different 
risks. Sustainable rural institutions have been boosted by sustainable agriculture that can encourage and augment the participation of all shareholders and promote the reconciliation of interests and benefits [31].

\section{4-Food Security and the Sustainable Agriculture}

In the opinion of the World Food Summit which held in 1996, Food security work out when whole people, at all times, they have material safe, economical access to enough nutritious and nourishment that use to meet their dietary of necessity and food preferences for an active and healthy life [10] [29]. According to the EC-FAO, 2008 report, the main four dimensions of food security can be specified: (i) food physical availability, (ii) economic and physical food accessibility, adequate supply of food at the domestic or global level does not in itself ensure the food security at the household level, (iii)food utilization, which is recognized as the method the body makes all the different nutrients in the food and final point was the stability of food security dimensions for a while. Even though your food intake is enough today, nevertheless your food will be considered insecure if you have unsuitable access to food on a periodical basis, the chance of decline of nutritional status, drastic weather conditions, political mutability, or economic factors such as unemployment and food price rises, may have an influence on your food security situation.

Fuel or food? This question has often been discussed in recent years, energy, crops of fibre and food such as cotton regularly contend for arable lands. This is a potential threat to global food security, also accompanied by increased global demand for biofuels, population growth, and demands for the highest quality food and nutrition. Speculation, all these conditions led to a rise in food prices where attention was considerable and notable in 2008 when social and political unrest broke out in many countries [31].

Biofuel has been considered a better in-utilize carbon footprint than fossil fuels, which makes it seems some more sustainable, but the closer view detects that its output highly resources and utilizes the soil and the water. Biofuel production in the cultivation of a single crop in a given area affects the variety of agricultural methods and biodiversity. Rainforest deforestation and the overindulgent use of fertilizers for increasing energy crops will reduce biofuels' carbon footprint [31].

In addition, sustainable farming practices and tools can create a career and increase the income in rural areas, which in turn share into raise food security. The advantage is to layout the land use and production by methods that enable plants and food to be produced in a sustainable way for energy and other critical use, so food crops and producing energy as parallels, beside by-products and residues efficiently. Nevertheless, increasing the world's steadily population must clearly take a particular place and priority [9].

The same status goes to the raising of the growth of animal feed because the global demand for the meat is significant; a worldwide output that provides the world's increasing population increased four times between 1963 and 2014 and predicted to increase by an additional 50 percent by 2050 . Pigs and poultry are mostly fed on cereal and soy, that considerable amounts are also used, with forages, to feed both dairy and beef [14].

Almost 40 percent of the cereal consumed and wasted around the world ends up for cattle, and feeding troughs, so more than 70 percent of land put to use for the farming globe is used for domestic animal breeding and feeding. However, the large number of the lands used for livestock breeding is adequate only for this objective, such as the pastureland used by nomads in some regions, so meat consumption can consequently help to secure the nutrients for the earth's population by the future.

\section{5-Indicators of measuring economic development}

The measures of economic development vary according to different development concepts, and growth indicators such as income or national products are not valid, because they are a quantitative measure. What is needed is the non-standard measurement, where it is difficult to measure development, for it includes social variables that are difficult to evaluate, such as the fairness of income distribution [2].

1. The Physical Quality of Life Index (PQLI): A composite social indicator reflecting the average of three indices: life expectancy at birth, literacy rate, and infant mortality rate [2].

2. KOSOV scale: According to this scale, it is possible to distinguish between two indices, the first of which is the growth index expressed as the growth rate of the gross product, the second is the development scale expressed as the growth rate of the gross product, in addition to the degree of change of the economic structure towards the most vital sectors.

\section{6-The main indicators which linked food security with sustainable agriculture in Hungary and OECD countries \\ 6.1 Food indicators}

The security of supply, which is the production of an adequate amount of food and fibres, is covered by indicators of export and import of agricultural products and production value of food processing within the processing industry. Although in the context of security of supply, the free trade in the European Union seems to be less important to meet its own needs, situations may arise for example natural disasters, when it can be of 
strategic importance, the 'food volatility index indicator is also linked to the issue of giving producers and consumers greater security when food prices are stable [39].

Food safety and food quality are linked to indicators of 'organic farming in proportion to agricultural land used and 'cultivation of genetically modified crop products in proportion to the utilized agricultural area. While the health of foods produced in organic farming - chemically free - is not disputed by experts (although there are some main fungicides that are more common in organic food in the absence of plant protection), the production of genetically modified plant products is shared by both experts and public opinion. Among the arguments that lie next to it is that in order to provide for the rapidly growing population of the Earth, there is a growing need for yields that can be achieved by the cultivation of genetically modified plants, and fewer chemicals are used for their production, and it is primarily about not knowing the full effects on the human and animal organism. The EU is increasingly united against the production of genetically modified plant products, which is why I have included the indicator in the indicator system. Food safety is also linked to the indicator of "microbiological, food-borne diseases per 100,000 people, which is a proxy indicator for the "food safety performance" of agriculture and the food sector, additionally to the inclusion of "per capita annual average consumption of vegetables and fruits", which covers the topic of healthy nutrition, the ratio of exports of processed food and agricultural products would have been a good indicator, but no suitable data source was found for this indicator.

The share of organic farming in the agricultural area used has increased, Austria ranked first in the ranking of countries (19.5\%) in 2010, while the highest growth was recorded in Latvia and Lithuania. Hungary ranked 23rd in the ranking of countries in 2010, and the rate of growth of organic farming was also low in Hungary in Europe. In 17 European countries (including Hungary) genetically modified (GMO) plant products have not been cultivated in the decade under review, which is due to the ban on GMO crop production in most countries. In the EU Member States, GMO plant products increased from $0.2 \%$ to $0.5 \%$ between 2000 and 2010. GMO production reached the highest rate in Spain (3.2), the Czech Republic (1.4) and Portugal (1.3) in 2010 [39].

The share of exports and imports of agricultural products (103) in the EU as a whole showed only a slight change between 2000 and 2010 (from 0.96 to 0.99), while the proportions of individual Member States have changed significantly. In 2000, Hungary had the most favourable foreign trade position of agricultural products in the EU, which reached the highest rate of decline over 11 years (1.5 in 2010). With this, Hungary still showed the third-best rate after Denmark and the Netherlands, and again in 2012, Hungary was the first among the EU member states. The largest growth occurred in Latvia and Romania. Among the EU Member States, small island states (Cyprus and Malta) are most in need of agricultural imports, followed by the United Kingdom and Finland in terms of the share of exports and imports [39].

The production value of food processing showed a slight increase for the EU as a whole between 2000 and 2010 (from 16.8\% to 17.9\%), while the share of the food industry has increased or stagnated in the older member states of the European Union, the decline in all of the newly acceding Eastern-Central European countries. The largest decrease occurred in Slovakia and the Czech Republic, while the most significant increase was in the UK and France. In 2010, the food industry reached its highest rate in Cyprus and Croatia, while the lowest in Slovakia and Sweden. In Hungary, the ratio decreased from $16.0 \%$ to $11.9 \%$ in the period under review.

The volatility of food prices showed a slightly different picture in time and space. For the EU as a whole, there was a decline between 2000 and 2005, followed by an increase after 2005, the most significant increase was seen in Slovenia and Germany, while the most significant decrease was seen in Italy, Poland and the Czech Republic. In 2010, the lowest volatility for Luxembourg and Italy, while the highest for Lithuania, Latvia, and Hungary and Slovakia were much lower than for the two countries [39].

\subsection{Environmental indicators}

Indicators of "greenhouse gas emissions per unit of value-added in agriculture and indicators of "ammonia emissions per unit of value-added in agriculture" are the emissions of agricultural pollutants. The nutrient balance of the soil is characterized by the indicators of "one hectare of nitrogen per hectare of utilized agricultural area" and "the proportion of organic manure used in total nutrient intake (N content)". The indicator "Sales of plant protection products per unit utilized agricultural area" is an approximate indicator of pesticide use [39].

The ratio of 'livestock and crop farms based on their standard output' is a form of sustainable agricultural activity. The 'change in the proportion of arable land within the utilized agricultural area' is an indicator from an environmental point of view shows an unfavourable change in the proportion of arable farming. Farmers' qualifications and agricultural training are concerned with the indicators of "standard output of a farmer with a higher education degree and the "proportion of graduates in agriculture and veterinary medicine as a percentage of all graduates". The inclusion of the two indicators was justified by the fact that the farmer with a higher level of agricultural education is presumed to be more attentive and more attentive to the environment. An instance of 
the latter is the use of water in agriculture - an important indicator of the environmental dimension of sustainable agriculture, but the quality of data for EU Member States did not allow it to be included in the indicator system - and waste agriculture. Indicators on soil erosion, soil quality and use of precision technology [39].

\subsection{Economic indicators}

Three indicators deal directly with efficiency, namely: "output per unit of intermediate consumption in agriculture" "gross value added per hectare of utilized agricultural area and the 'unit labour value added in agriculture' indicator. The three indicators look at the effectiveness of inputs, agricultural land used and labour used. The 'grain yield per hectare' indicator gives an overview of the efficiency of a country's agriculture through yields. The indicator of the "share of agricultural exports and imports" shows the competitiveness of the country's agricultural trade, the "non-utilized agricultural area for all agricultural products", "Ensuring economic viability and profitability", the indicator "gross fixed capital formation in agriculture per unit of depreciation" provides an indication of the replacement of depreciated production assets, which is an essential factor in viability. An essential indicator of viability - the diversified activity of farms - is the indicator of "standard output of non-agricultural holdings as a percentage of total standard output". The research and development in agriculture" characterizes research and development as one of the conditions for viability. The age composition of farmers is also an essential aspect of viability as if the farmer population is ageing, and their place is not taken over by younger ones, it will harm viability. Information on this is provided by the indicator "Proportion of farmers under 35 years of age and over 65 years in standard output". "Agricultural income development" this indicator gives a general picture of the profitability of agricultural production. The viability of agricultural production, if the profitability of agricultural production is less dependent on subsidies, is addressed by the indicator "agricultural subsidies as a percentage of added value" [39]

\subsection{Social indicators}

The ratio of "per capita GDP in rural areas to national data" (401) is characterized by variations in the level of development of rural areas, while the indicator "per capita rural development support in rural areas" gives an indication of rural development support. The indicator "rate of change of the rural population" and the indicator of "dependency of 65 years of age on the rural population" deal with the demographic characteristics of the rural population that are important for sustainability. The 'employment rate in sparsely populated areas (20-64 years)' is an indicator of employment, while 'poor households in sparsely populated areas' and 'low-density housing in sparsely populated areas' Indicators of poverty and housing conditions. Indicators of "households with Internet access in sparsely populated areas" and "pollution incidence in residential areas in sparsely populated areas" characterize sparsely populated areas in terms of penetration of the Internet and subjective perception of environmental pollution [39].

Among the indicators of 'society' (improvement of the quality of life in rural areas, social justice, attractive rural environment and landscape design), the value creation indicator (the ratio of GDP per capita in rural areas to national data) is negligible. Declined between 2000 and 2010 for the EU as a whole (from 78.7\% to 77.4\%). In 2010, rural GDP in the Netherlands and Italy was the highest in terms of national data. In the sparsely populated areas, the employment rate has hardly increased in the EU average between 2000 and 2010, from $66.1 \%$ to $67.1 \%$. Growth was highest in Italy, while the largest decrease occurred in Romania and Lithuania. The highest employment rate in Sweden was reported in 2010, while the lowest in Hungary (58.9\%, 60.4\% in 2000).

The rate of rural development support per capita in rural areas increased from $€ 55.5$ to two and a half, to $€$ 138.9 per capita on average in EU Member States between 2000 and 2010. In 2010, the Netherlands had the highest per capita value, and the lowest in Croatia, while in Hungary it was 96.9 euros, which was below the EU average. The rate of change in the population in rural areas deteriorated from 3.45 to 1.19 between 2000 and 2010, averaged over EU member states, which led to a decline in the previous growth rate for rural population from 2009 onwards. The rate deteriorated most in Lithuania, while the most significant improvement was observed in Sweden. In 2010, the most favourable change in the rural population was characterized by Belgium and Luxembourg, while Lithuania and Latvia were the most unfavourable. Hungary was also among the developing countries: the rate of change of the rural population decreased from -3.9 to -7.3 in the examined period [39].

The proportion of poor households in sparsely populated areas decreased in EU member states between 2000 and 2010, from an average of $32.4 \%$ to $28.1 \%$. It was lowest in the Netherlands, Austria and Sweden in 2010, while Bulgaria, Romania and Latvia had the highest poverty rates. In Hungary, the poverty rate declined between 2000 and 2008, then began to increase, reaching 34.7\% in 2010 and $37.9 \%$ in 2012, above the 2000 level. 
The proportion of households living in severe housing conditions in sparsely populated areas fell from $13.5 \%$ to 7.7\% in the decade after 2000 for the EU as a whole. In 2010, the lowest rates were recorded in Belgium, the Netherlands and Ireland, while the highest rates were in Romania, Latvia and Hungary (19.1\%) [39].

Indicator of the age composition of the population - the dependency ratio of those over 65 in the rural population, which measures the proportion of people over 65 years of age compared to the active age group, showed an unfavourable trend: from 26.7 to $28.5 \%$ in 2000 and 2010 EU average. In almost all EU countries, the value of the indicator increased during the period under review, most notably in Denmark. In 2010, Spain and Greece had the worst rural age composition, while the least-aged rural population lived in Slovakia, Ireland and Poland. The Hungarian rural population was ageing below the EU average in 2010; the value of the indicator increased from $21.7 \%$ to $24.4 \%$ in the period under review. Among the indicators of "society", the indicators for Internet access, rural development support, housing conditions, environmental damage, poverty and employment are favourable for the EU as a whole. At the same time, population change, age composition and population are unfavourable in terms of gross value added in rural areas. [39].

\section{7-Agricultural area and food production in Hungary}

agricultural census (AC) until 2010 had been considered as 567 thousand private holdings and 8800 agricultural enterprises, the number of private holdings were decreasing between 2000 and 2007 and consequently the number of enterprises had attained a lightly increase [21].

The areas which were applied for agriculture have decreased by 300,000 ha, on one side portions of cereal take up to about $70 \%$ of all arable lands, and the significant cereals are maize and wheat. The average yield of maize $65 \mathrm{t} / \mathrm{ha}$ and the wheat is $45 \mathrm{t} / \mathrm{ha}$, and other significant crops are potatoes, oilseeds, fruits, vegetables, and wine grape, on the other side Livestock accounts for $40 \%$ of the total agricultural production of livestock, $70 \%$ of cattle and cows, $63 \%$ of pigs and $50 \%$ of poultry are raised in farms (cooperative farms and companies). However, $86 \%$ of sheep are kept in individual farms, before moving, sheep were raised on larger farms [1].

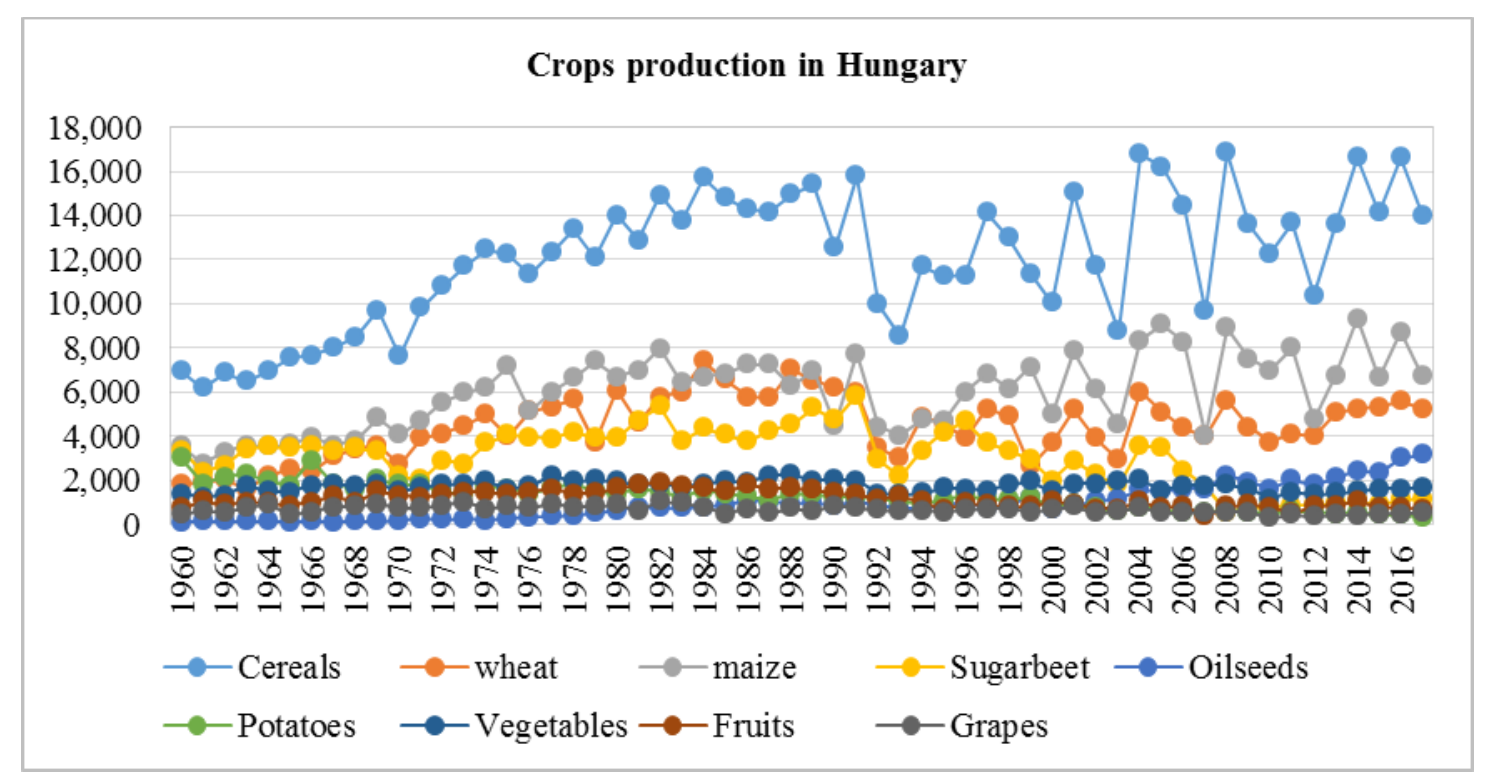

Figure 1. crops production in Hungary from 1960-2016.

\section{8-Emission Gas Greenhouse (EGG)}

Farmers usually want to produce and sell products, but GHG reduction is severe by this sense. It takes on an integrated and comprehensive food systems way ("from farm to fork") will be essential to support coherent and harmonious changes along the entire chain included to promote more sustainability in agriculture, to healthier food, and finally to have an effective reduction of food waste through using ecosystem services, such as clean water bodies accountable and biodiversity in the same units with GHGs. Focusing on the debate about climatesmart agriculture, an integrated view of agricultural systems is complicated, but it is due, farmers and politicians require simple guidance, counsel, and advice [13] Organic agriculture practices which have been provided to reduce GHG, the following points: animal waste, nutrient management, livestock management, soil management, crop management, crop legume rotation [41], sustainable agriculture and improvement of quality of environmental, will be at the forefront in realizing mitigation challenge and potential in agriculture. 
Ola Al Jaafreh, Imre Nagy., 2020. Food Security and Sustainable Agriculture: A Case of Hungary /American-Eurasian Journal of Sustainable Agriculture. 14(1): 1-13.DOI: 10.22587/aejsa.2020.14.1.1

\section{9-Value added in the agricultural sector in Hungary}

Despite the decrease in the key factors that connects agriculture to the macroeconomic, agriculture has a remarkable role in the economy. For example, after 1990 earlier economic inactivity shows a dramatic increase while labor intensification of agricultural activities declines, agriculture played a prominent role in Hungary even when the industry was highly preferred in the socialistic economic policy [19].

The changing of production and ownership coincided with the small role of domestic and foreign market opportunities after the transition, and there was a sharp drop in production, profitability and significant narrowing in financial opportunities [19].

About $70 \%$ of the lands of the country is appropriate for agricultural production, while one-third of the terrains and soils are unfavourable for efficient and effecting farming and because there is a great part of the country is considered lowland [1].

The role of agriculture in the national economy is the best characterized by the continuously shrinking share of agriculture in GDP, so in (figure 2) in 1990 the share of agriculture was 12.5\% compared with it in 1985 which was almost 20\% of GDP, in 2004 it was decreased to 4.5\% and stayed nearly the same until 2017.

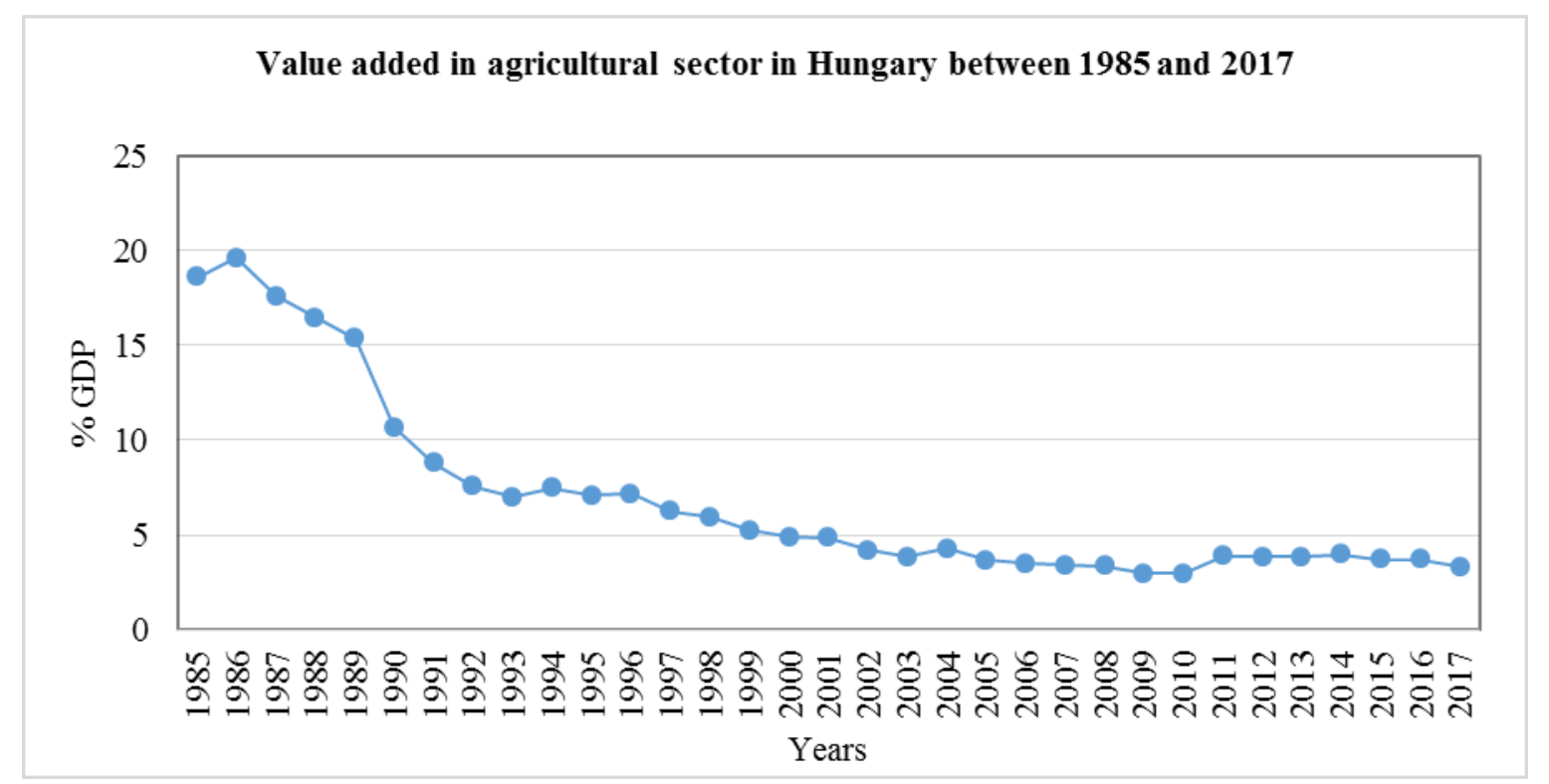

Fig 2. value added in the agricultural sector in Hungary

\section{0-Fertilizer consumption in Hungary}

Through the progressive reforms, the Common Agricultural Policy has improved European agriculture's market trends and orientations with providing income support and assistance to farmers. Improving the integration and combination of environmental requirements, and fortified support for rural development as an integrated policy for the development of countryside areas across the EU. The same repair process has increased demands for a better distribution of support through and within the Member States, further to call for better targeting of measures aimed at addressing the environmental challenges and the increased market volatility [12]. The worldwide challenge for farmers and their affiliates will be to increase production in a sustainable manner that reduces environmental impact and at the same time provides enough, safe, and nutritious products. Many believe that biotechnology holds the key to higher food production rates, but it is only one piece of the puzzle. The employment and further progress of many technologies (irrigation, equipment, pest control, fertilizers, and seeds) will be required to confront the challenge ahead while bridging the gap between actual and potential yields. Hence, the positive interactions between many advanced technologies carry the key. Nutrient management, practices, and fertilizer technologies are among those that demand continuous improvements because adequate and balanced nutrition is the basis for healthy crops [34].

According to [24], the world population grows, so there will be increasing demands for increased agricultural production. These demands exacerbate the difficulty of managing agriculture sustainably. The study showed the importance of defining so-called marginal productivity concerning the effective use of chemical fertilizers, also it concluded to that structural differences in agriculture have a significant impact on the calculation of biological capacity, and suggest a reflecting on how this indicator has been calculated so far. So it suggested that the long-term environmental impact of intensive agricultural practices should be built on the ecological footprint model; that is, the factors involved in national productivity must be adjusted when calculating the country's biological capacity. 
Ola Al Jaafreh, Imre Nagy., 2020. Food Security and Sustainable Agriculture: A Case of Hungary /American-Eurasian Journal of Sustainable Agriculture. 14(1): 1-13.DOI: 10.22587/aejsa.2020.14.1.1

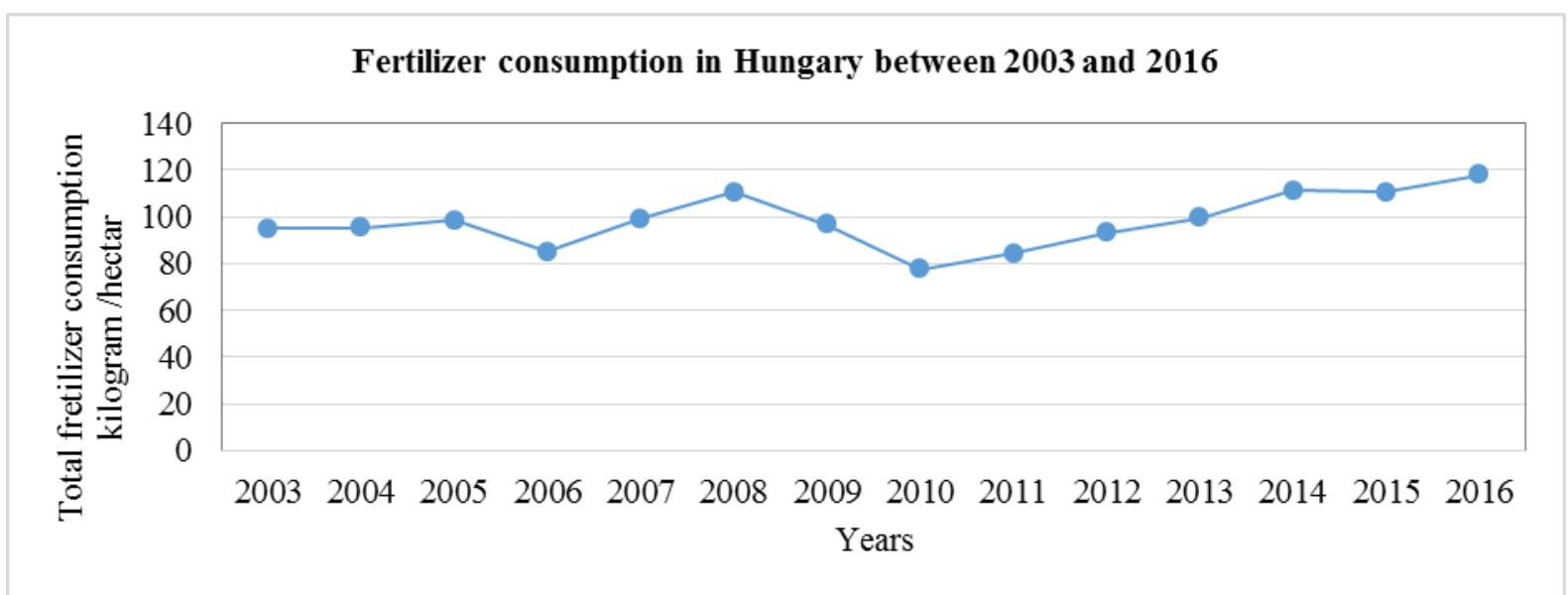

Fig 3. fertilizer consumption in Hungary, Source: Own author

\section{Aim of the study:}

\section{METHODOLOGIES}

The study was designed to examine the relationship between selected variables that shared between sustainable agriculture by its indicators and food security by its determinants in Hungary in the long term, Study the relationship and effect between variables conclude to effect of sustainable agriculture on food security, variables used in the study were chosen based on their impact on sustainable agriculture and/or food security.

\section{Data Collection}

The study uses observations of the term between 1980 to 2016 for seven variables. All variables are expressed in logs. Furthermore, The data sets were obtained from International Finance Statistics (IFS), Food and Agriculture Organization (FAO), the Statistics, Hungarian Central Statistic Office (HCSO), and World Bank (WB). The seven variables used in this paper are defined as follows:

1. Food production index (FPI): involves food crops which considered edible for human consumption and contain nutrients except for Coffee and Tea, because despite them being edible, they do not have nutrient value

2. Emission Gas Greenhouse (EGG): it is considered as an indicator of sustainable agriculture, defined in Metric tons of carbon dioxide equivalent $\left(\mathrm{MtCO}^{2} \mathrm{e}\right)$.

3. Real gross domestic product (GDP): is a measure of total production for the Hungarian economy, this variable is expressed in HUF million.

4. Fertilizers consumption (F): it is considered as a tool and indicator of sustainable agriculture. The variable collected is expressed in kilogram/hectare.

5. Organic Farming (OF): it is considered as a tool and indicator of sustainable agriculture, expressed in hectares.

6. Hungarian Population (P): the variable is regarded as an indicator for both sustainable agriculture and food security. This variable is expressed in million individuals.

7. Agriculture Area Hectares (AAH): it is considered as an indicator of sustainable agriculture, expressed in hectares.

\section{Study Hypothesis}

The study has one hypothesis, which is:

H1: indicators of sustainable agriculture and food security determinants have a positive relationship with each other's

\section{Data Analysis}

The collected data were subjected to analysis by using the Gretl program (version 2017, YEAR). Results were summarised cointegration relations to examine the relationship between the variables, using the VAR model. Regression and multicollinearity were applied to investigate evidence of variable impact on other variables. The invariable significant difference was determined under the P-Value $<0.05$. The seven variables, which are macroeconomic variables, were chosen based on work of Metz and Thomson (1998)[36], Lemtouni and Aker (1999)[5] but in this model, the variables were chosen and replaced to represent food security and sustainable agriculture separately or jointly to study the impact of each of these variables on each other directly and 
Ola Al Jaafreh, Imre Nagy., 2020. Food Security and Sustainable Agriculture: A Case of Hungary /American-Eurasian Journal of Sustainable Agriculture. 14(1): 1-13.DOI: 10.22587/aejsa.2020.14.1.1

indirectly on each of the food security And sustainable agriculture, given these variables are determinants and indicators for both terms, depending on the empirical model which outlined in Lemtouni and Aker (1999)[5], the food security has been considered as the dependent variable, but in this model food security has been represented by indicators which are common between sustainable agriculture and food security to investigate how these indicators or somehow determinators influenced by each other in long term years from 1980 to 2016. The food production index has been included because it's related to food production which is the main goal for getting ecologically and economically sustainable to meet the world need as well, The pattern of sustainable agriculture most chosen or practised by local proponents is "organic agriculture" or "organic farming". Organic agriculture is a holistic production system, which promotes and consolidate biodiversity, biological rotation, and soil biological activity, however, the link comes indirectly with GHG emissions depending on the farming system form[18], at the same time food security has been as a response of the production aspect, the fertilizers which consider as an indicator of sustainable agriculture also consider as drivers to food production to reach the food security [28]. The using of RGDP is compatible with previous literature that uses income as one of the factors which affect food security, (see Ahmed \& Siddique, 1995)[4], Hungarian population reflects the increasing or decreasing population in a country.

\section{Empirical Results}

This section shows the empirical results of the data analysis, which begins with the summary of the unit root test the stationarity of the variables used to test the empirical study. Augmented Dickey-Fuller (1979) tests were employed. Table (1) shows that the variables expressed at the level are non-stationary but when all the variables are first differenced there is evidence that all the variables are stationary.

Table 1: Unit root test results

\begin{tabular}{|c|c|c|c|c|}
\hline \multirow{2}{*}{ Variable } & \multicolumn{2}{|c|}{ Level } & \multicolumn{2}{c|}{$1^{\text {st }}$ difference } \\
\cline { 2 - 5 } & No Trend & With Trend & No Trend & With Trend \\
\hline FPI & -0.147 & -0.132 & $-0.010^{*}$ & $-0.032^{*}$ \\
\hline P & 0.042 & 0.098 & $0.045^{*}$ & $0.044^{*}$ \\
\hline GDP & 0.087 & 0.020 & $-0.031^{*}$ & $-0.030^{*}$ \\
\hline OF & -2.85696 & 0.032 & $-0.023^{*}$ & $-0.021^{*}$ \\
\hline F & -0.000 & 0.058 & $-0.033^{*}$ & $-0.058^{*}$ \\
\hline EGG & 0.802 & 0.875 & $0.660^{*}$ & $0.635^{*}$ \\
\hline AAH & -0.074 & 0.078 & $-0.009^{*}$ & $-0.082^{*}$ \\
\hline
\end{tabular}

*= significant at 5\% *FPI= Food Production Index, $\mathrm{P}=$ Population, GDP= Real Gross Domestic Product, $\mathrm{OF}=$ Organic Farming, F= Fertilizer, EGG= Emission Gas Greenhouse, AAH= Agriculture Area Hectares.

The next step is to test if there is a long-run relationship exists among the variables by using a cointegrating relations method. Table 2 presents the Johansen test for the cointegration relations among all seven variables, on the basis of trace statistics and the maximal eigenvalue statistics at 5 percent. The trace statistic reveals that there is one cointegrating relationship among seven variables. Since the trace statistic considers all of the smallest eigenvalues, it possesses more power than the maximum eigenvalue statistic. Johansen and Juselius (1990) recommend the use of the trace statistic when there is a conflict between these two statistics. Therefore, this result indicates that there is a long-run relationship between these seven variables. In other words, the variables have also cointegrated the equations of the VAR, including the lagged values of the variables in levels to capture their long-run relationships.

Table 2: Cointegration test results

\begin{tabular}{|c|c|c|c|c|}
\hline \multirow{2}{*}{ Null hypothesis } & \multirow{2}{*}{ Trace statistics } & \multirow{2}{*}{ Maximal eigenvalue statistics } & \multicolumn{2}{|c|}{ Critical Values (5\%) } \\
\cline { 3 - 5 } & & & Trace & Max-Eigen \\
\hline $\mathrm{r}=0$ & 131.13 & 41.635 & 153.57 & 42.085 \\
\hline $\mathrm{r} \leq 1$ & 89.493 & 32.216 & 111.49 & 41.595 \\
\hline $\mathrm{r} \leq 2$ & 57.277 & 23.255 & 69.893 & 25.501 \\
\hline $\mathrm{r} \leq 3$ & 34.022 & 21.505 & 44.392 & 21.791 \\
\hline $\mathrm{r} \leq 4$ & 12.517 & 9.6242 & 22.601 & 13.151 \\
\hline $\mathrm{r} \leq 5$ & 2.8930 & 2.7557 & 9.4497 & 6.8504 \\
\hline $\mathrm{r} \leq 6$ & 0.13732 & 0.13732 & 2.5994 & 2.5994 \\
\hline
\end{tabular}

The output of the regression is presented in Table 3. With several lags of the same variables, each estimated coefficient might not be statistically significant due to multicollinearity. The VAR result reveals the statistical 
Ola Al Jaafreh, Imre Nagy., 2020. Food Security and Sustainable Agriculture: A Case of Hungary /American-Eurasian Journal of Sustainable Agriculture. 14(1): 1-13.DOI: 10.22587/aejsa.2020.14.1.1

and theoretical significance of the parameter estimate. The results show that population (p), gross product index, fertilizer (F), emission gas greenhouse (EGG), and agriculture area hectares (AAH) have a significant positive impact on food production index (FPI). In contrast, the results show that organic farming has an insignificant impact on FPI.

Table 3: Vector Auto-Regressive estimates

\begin{tabular}{|c|c|c|c|c|c|c|c|}
\hline Variable & FPI & $\mathbf{P}$ & GDP & OF & $\mathbf{F}$ & EGG & AAH \\
\hline FPI_1 & $0.414(0.311)$ & $\begin{array}{c}-0.004 \\
(-0.0002)\end{array}$ & $\begin{array}{l}-0.208 \\
(0.340)\end{array}$ & $\begin{array}{c}0.547 \\
(-0.173)\end{array}$ & $\begin{array}{c}-0.142 \\
(0.498)\end{array}$ & $1.738(2.099)$ & $\begin{array}{c}0.023 \\
(-0.061)\end{array}$ \\
\hline$P_{-} 1$ & $-4.029(8.288)$ & $1.327(-0.439)$ & $\begin{array}{c}-26.19 \\
(-10.34)\end{array}$ & $\begin{array}{l}-49.62 \\
(44.63)\end{array}$ & $\begin{array}{l}-3.031 \\
(4.480)\end{array}$ & $\begin{array}{c}54.98 \\
(-26.62)\end{array}$ & $\begin{array}{l}-1.803 \\
(2.947)\end{array}$ \\
\hline GDP_1 & $\begin{array}{c}-0.051 \\
(-0.0142)\end{array}$ & $\begin{array}{c}-0.0001 \\
(0.001)\end{array}$ & $0.188(0.024)$ & $\begin{array}{l}-0.110 \\
(0.004)\end{array}$ & $\begin{array}{l}-0.050 \\
(0.039)\end{array}$ & $\begin{array}{c}-0.109 \\
(-0.321)\end{array}$ & $\begin{array}{c}-0.004 \\
(-0.002)\end{array}$ \\
\hline $\mathrm{OF}_{-} 1$ & $\begin{array}{c}-0.116 \\
(-0.191)\end{array}$ & $\begin{array}{c}0.0004 \\
(-0.001)\end{array}$ & $\begin{array}{l}-0.530 \\
(0.130)\end{array}$ & $\begin{array}{c}0.368 \\
(-0.072)\end{array}$ & $\begin{array}{l}0.0621 \\
(0.136)\end{array}$ & $\begin{array}{l}-0.181 \\
(0.087)\end{array}$ & $\begin{array}{l}-0.026 \\
(0.008)\end{array}$ \\
\hline$F_{-} 1$ & $0.388(0.053)$ & $0.005(-0.009)$ & $\begin{array}{c}0.196 \\
(-0.228) \\
\end{array}$ & $\begin{array}{c}0.581 \\
(-0.088) \\
\end{array}$ & $\begin{array}{c}0.230 \\
(-0.111) \\
\end{array}$ & $\begin{array}{c}-0.247 \\
(-1.116) \\
\end{array}$ & $\begin{array}{c}0.088 \\
(-0.002) \\
\end{array}$ \\
\hline EGG_1 & $0.001(0.024)$ & $0.0007(0.001)$ & $0.745(0.773)$ & $\begin{array}{l}-0.026 \\
(0.103)\end{array}$ & $\begin{array}{c}0.0261 \\
(0.0482)\end{array}$ & $\begin{array}{c}-0.498 \\
(-0.366)\end{array}$ & $\begin{array}{c}-0.003 \\
(-0.002)\end{array}$ \\
\hline AAH_1 & $-1.891(0.453)$ & $0.032(0.006)$ & $\begin{array}{l}-0.075 \\
(3.342)\end{array}$ & $\begin{array}{l}-0.190 \\
(0.883)\end{array}$ & $\begin{array}{c}-0.217 \\
(-2.202)\end{array}$ & $\begin{array}{c}-3.743 \\
(-6.862)\end{array}$ & $0.583(0.146)$ \\
\hline R-squared & 0.801 & 0.995 & 0.925 & 0.583 & 0.846 & 0.763 & 0.972 \\
\hline $\begin{array}{l}\text { Adj. R- } \\
\text { squared }\end{array}$ & 0.663 & 0.991 & 0.872 & 0.292 & 0.738 & 0.597 & 0.953 \\
\hline $\begin{array}{l}\text { Sum sq. } \\
\text { resids. }\end{array}$ & 0.158 & 0.0001 & 0.785 & 0.625 & 0.088 & 2.123 & 0.004 \\
\hline S.E. equation & 0.089 & 0.002 & 0.198 & 0.176 & 0.066 & 0.325 & 0.015 \\
\hline P-value & 0.0002 & $4.56 \mathrm{e}-20$ & $2.86 \mathrm{e}-08$ & 0.076 & 0.000 & 0.001 & $1.57 \mathrm{e}-1$ \\
\hline $\begin{array}{c}\text { Log } \\
\text { likelihood }\end{array}$ & 45.62 & 36.073 & -142.732 & 167.413 & -52.652 & 52.021 & 42.761 \\
\hline Akaike AIC & 19.46 & 12.301 & 2.092 & -0.301 & 0.715 & 12.541 & 3.098 \\
\hline $\begin{array}{c}\text { Mean } \\
\text { dependent }\end{array}$ & 4.995 & 16.14 & 16.70 & 7.394 & 4.296 & 9.229 & 8.698 \\
\hline $\begin{array}{c}\text { S.D. } \\
\text { dependent }\end{array}$ & 0.153 & 0.025 & 0.556 & 0.210 & 0.129 & 0.513 & 0.072 \\
\hline
\end{tabular}

FPI_1= Food Production Index, P_1= Population, GDP_1= Real Gross Domestic Product, OF_1= Organic Farming, F_1= Fertilizer, EGG_1= Emission Gas Greenhouse, AHH_1= Agriculture Area Hectares.

\section{DISCUSSION AND CONCLUSION}

This paper analyzed the dynamic relationship between Macroeconomic variables which have been chosen to be the link between sustainable agriculture and food security by the selection of some indicators of sustainable agriculture (Emission gas Greenhouse, Fertilizers consumption, Organic Farming, Agriculture Area) and some other related variables (Hungarian Population, Real gross domestic product). Subsequently, to examine the effect of each variable in a long time series (1980-2016) through each other's, also the effects of those variables on FPI, In contrast, the GDP had a positive relationship with all variables except organic farming, which make the opposite side with the study [26] of that considered the GDP affected positively with all macroeconomic and environmental variables.

The results showed that the data of variables which had been selected in this study depending on (Dick Fuller) tests, that all are stationary, also there is long term relationship between all seven variables. Furthermore, there is a significant positive impact of EGG, AAH, F, GDP, and P on FP, while the effect of OF on FPI was insignificant. The recommendation is increasing and improving organic farming with an effective method to reach the massive food production with sustainable products.

The results indicate the positive relationship between greenhouse gas emissions and the use of fertilizers and the agricultural production index, where this result corresponds to the study [23] of greenhouse gases that concluded a positive effect between greenhouse gases resulting from agricultural consumption and fertilizers, which explained this increase to the slow increase in the volume of irrigated agricultural lands. In the results as well, the relationship was negative in relation to organic farming with the rest of the variables. This is a logical 
result in respect of the relationship between the use of fertilizers and the agricultural production index positively, while the use of fertilizers was harmful with the production of organic agriculture because the fertilizers used are inorganic or the using extensively for non-biological fertilizers. This result is also compatible with the study [22], which concluded that the emission ratios differ with the use of multiple-source fertilizers, which recommended the encouragement of the recycling of agricultural waste, thus preserving the soil from depletion and preparing it for more organic production. On the other side the positive relationship between growth population with the food production index, it will cause big challenges to maintain food security with the sustainability at the same time particularly with the vulnerable population, because of food insecurity occur when estimated per capita food consumption for a consumer at a certain income level shorts of nutritional target of 2.100 calories per person per day depending on[35]. The food production should be increased more than the rising population, with sustainable ways to get sustainable agriculture and food security in parallel with each other.

\section{CONTRIBUTION OF THE STUDY}

The study confirmed through research, analysis, and conclusion that the systematic path must be followed to obtain sustainable agriculture and food security achieved because many indicators and determinants of both are overlapping and affecting each other directly or indirectly. This leads the decision-maker who is the direct responsibility for both sustainable agriculture and food security should be in constant contact with the scientific research regarding both agricultural production and the environment with the increasing of research development in both fields.

\section{REFERENCES}

[1] A., Burger, 2009. The situaton of Hungarian agriculture. Institue of Economics of Hungarian Academy of Sciences. Available at: http://econ.core.hu/file/download/konfea/burgerne.doc.

[2] A.K., Ray, 2012. Measurement of Social Development: An International Comparison. Journal of Social indicator Research, 86(1), 1-46. Retrieved from www.jstor.org/stable/27734602

[3] A.P, Haller, 2012. Concepts of Economic Growth and Development. Challenges of Crisis and of Knowledge. Economy Transdisciplinarity Cognition, 15(1), 66-71. Available at: https://pdfs.semanticscholar.org/c458/227f9ec35d1797144ab64bd550ad20e3ed90.pdf.

[4] Ahmad, A., \& Siddiqui S. (1995). Food Security in Pakistan: Can it be achieved? The Pakistan Development Review, 34(4), 723-731. Available at: http://www.pide.org.pk/pdf/PDR/1995/Volume4/723-731.pdf

[5] Aker, J.C., \& Lemtouni, A. (1999). A Framework for Assessing Food Security in the Face of Globalization: The Case of Morocco. Agroalimentaria, 8, 13-26.

[6] Berry, E.M., S., Dernini, B., Burlingame, and A., Meybeck, 2015. Food security and sustainability: Can one exist without the other?. public health nutrition journal, 18(13):2293-302. https://doi.org/10.1017/S136898001500021X.

[7] C., Kwong, 2009. Macroeconomics Series ( 3 ): Economic Growth and Development. seminar for NNS economics curriculum. Available at: https:/www.edb.gov.hk/attachment/tc/curriculumdevelopment/kla/pshe/references-andresources/economics/Economic\%20Growth\%20and\%20Development(File\%205.2).pdf.

[8] Cervantes-godoy, D., and J., Dewbre, 2010. Economic Importance of Agriculture for Poverty Reduction. OECD Food, Agriculture and Fisheries Working Papers, No. 23, OECD Publishing. https://doi.org/10.1787/5kmmv9s20944-en.

[9] Deelstra, T., H., Girardet, 2000. Urban agriculture and sustainable cities. In Growing Cities, Growing Food: Urban Agriculture on the Policy Agenday; Bakker, N., Dubbeling, M., Gundel, S., Sabel-Koschela, U., de Zeeuw, H., Eds.; Deutsche Stiftung fur Internationale Entwicklung (DSE): Feldafing, Germany, 2000; pp. 43-65. Available at: https://pdfs.semanticscholar.org/18af/2772849baf476bf2841d58c4fc0f90ec5551.pdf.

[10]EC-FAO (Food Security Programme; Agriculture and Economic Development Analysis Division), 2008. An Introduction to the Basic Concepts of Food Security. Food Security Information for Action Practical Guides, 1-3. Avialable at: http://www.fao.org/3/al936e/a1936e00.pdf.

[11]FAO (Food and Agricultural Orgnization of Untied Nation), 2018. Sustainable Agriculture for Biodiversity. Biodiversity for Sustainable Agriculture. FAO puplisher, 1-48. Available at: http://www.fao.org/3/I6602E/i6602e.pdf. 
[12]FE (Fertilizers Europ), 2012. Forecast of food , farming and fertilizer use in the European Union 20122022: report. Available at: https://www.fertilizerseurope.com/wpcontent/uploads/2019/08/Forecast_2012-final.pdf.

[13]FMFA (Federal Ministry of Food and Agricutlure), 2018. Summary Report : International Conference on Agricultural GHG, Emissions and Food Security - Connecting research to policy and practice, September 10 - 13, 2018, Berlin, Germany. Available at: https://www.agrighg-2018.org/fileadmin/ghgagriculture/AgriGHG2018_SummaryReport.pdf.

[14] Global Agriculture, 2016. Agriculture at a Crossroads: IAASTD findings and recommendations for future farming. Foundation on Future Farming publisher, Germany. Available at: https://www.globalagriculture.org/fileadmin/files/weltagrarbericht/EnglishBrochure/BrochureIAASTD_ en_web_small.pdf.

[15] Hans J M van Grinsven et al, 2015. Environ. Res. Lett. 10 025002. Available at: https://iopscience.iop.org/article/10.1088/1748-9326/10/2/025002

[16] HLPE, 2014. Food losses and waste in the context of sustainable food systems. A report by the High Level Panel of Experts on Food Security and Nutrition of the Committee on World Food Security no. 8, Rome 2014. available at: http://www.fao.org/3/a-i3901e.pdf.

[17] HLPE, 2016. Food losses and waste in the context of sustainable food systems.A report by the High Level Panel of Experts on Food Security and Nutrition of the Committee on World Food Security no. 8, Rome 2014. available at: http://www.fao.org/3/a-i3901e.pdf.

[18] Hosam E. A. F. Bayoumi Hamuda and István Patkó, 2011. Strategy for Improve the Global Food Production. Óbuda University e-Bulletin, Vol. 2, No. 1, Available at: http://uni-obuda.hu/ebulletin/Hamuda_Patko_2.pdf.

[19] Judit, B and I, Fehér, A. schlett, 2014. Agriculture strategic role the economic social and enviromental dimension of sustainable agriculture in hungary; Bourges, L.A., Espada E.M., 2014. Agricultura familiar: reflexiones desde cinco continentes en el Año Internacional de la Agricultura Familiar 2014. Available at: http://real.mtak.hu/26926/1/SKMBT_C22015091813000.pdf.

[20] Judit, B. and I. Fehér, 2013. The Rationale of Sustainable Agriculture. Iustum aequum salutare 3: 73-88. Available at: http://ias.jak.ppke.hu/hir/ias/20133sz/03.pdf.

[21] KSH (Hungarian Central Statistical Office), 2013. Agriculture in Hungary. Hungarian Central Statistical Office series 2013. Available at: https://www.ksh.hu/docs/hun/xftp/idoszaki/mo/hungary2013.pdf.

[22] Mariangela D, A ,Persiani , E, Testani , F, Montemurro and C, Ciaccia. 2019. Recycling Agricultural Wastes and By-products in Organic Farming: Biofertilizer Production, Yield Performance and Carbon Footprint Analysis. Sustainability, 11, 3824; doi:10.3390/su11143824

[23] Mihaela S , Y, Bilan , S ، Edek , and D,Streimikiene.2019. The Effects of Greenhouse Gas Emissions on Cereal Production in the European Union. Sustainability, 11, 3433; doi:10.3390/su11123433

[24] Mózner, Z., A.,Tabi, and M., Csutora, 2012. Modifying The Yield Factor Based on More Efficient Use of Fertilizer - The Environmental Impacts of Intensive and Extensive Agricultural Practices. Ecological Indicators, 16:58-66. https://doi.org/10.1016/j.ecolind.2011.06.034

[25] Nighat ,H, Madeeha ,N, Muhammad R, Y. 2019. Relationship between Food Security, Macroeconomic Variables and Environment: Evidences from Developing Countries. Journal of Applied Economics and Business Research JAEBR, 9(1): 27-37.

[26] Nkomok W, M, Bavorová, and J, Banout. 2019. Factors Associated with Household Food Security in Zambia. Sustainability, 11, 2715; doi:10.3390/su11092715.

[27] Peng, W., Berry, E.M., 2019. The Concept of Food Security. In: Ferranti, P., Berry, E.M., Anderson, J.R. (Eds.), Encyclopedia of Food Security and Sustainability, vol. 2, pp. 1-7. Elsevier. ISBN: 9780128126875.

[28] Porter, J.R., L. Xie, A.J. Challinor, K. Cochrane, S.M. Howden, M.M. Iqbal, D.B. Lobell, and M.I. Travasso, 2014: Food security and food production systems. In: Climate Change 2014: Impacts, Adaptation, and Vulnerability. Part A: Global and Sectoral Aspects. Contribution of Working Group II to the Fifth Assessment Report of the Intergovernmental Panel on Climate Change [Field, C.B., V.R. Barros, D.J. Dokken, K.J. Mach, M.D. Mastrandrea, T.E. Bilir, M. Chatterjee, K.L. Ebi, Y.O. Estrada, R.C. Genova, B. Girma, E.S. Kissel, A.N. Levy, S. MacCracken, P.R. Mastrandrea, and L.L.White (eds.)]. Cambridge University Press, Cambridge, United Kingdom and New York, NY, USA, pp. 485533, Available at: https://www.ipcc.ch/site/assets/uploads/2018/02/WGIIAR5-Chap7_FINAL.pdf .

[29] R., Stringer, 2016. Food Security Global Overview. Journal of Food Poverty and Insecurity: International Food Inequalities 11-18. https://doi.org/10.1007/978-3-319-23859-3

[30] Reytar, K., C., Hanson, and N., Henninger, 2014. Indicators of Sustainable Agriculture: A Scoping Study. Creating a Sustainable Food Future project. Available at: http://agri.ckcest.cn/file1/M00/0E/C8/Csgk0F14pySAJ3LZAAWPIzdRhtk633.pdf. 
Ola Al Jaafreh, Imre Nagy., 2020. Food Security and Sustainable Agriculture: A Case of Hungary /American-Eurasian Journal of Sustainable Agriculture. 14(1): 1-13.DOI: 10.22587/aejsa.2020.14.1.1

[31] S., Krall, 2015. What is sustainable agriculture?. Published by Deutsche Gesellschaft für Internationale Zusammenarbeit (GIZ) GmbH, Available at: https://www.giz.de/en/downloads/giz2015-en-what-issustain-agric.pdf.

[32] SDSN (Sustainable Development Solutions Network), 2013. Solutions for Sustainable Agriculture and Food Systems : technical report for the post-2015 development agenda. Prepared by the Thematic Group on Sustainable Agriculture and Food Systems of the Sustainable Development Solutions Network, Available at: http://www.dun-eumena.com/reagri/upload/files/130919-TG07-AgricultureReport-WEB.pdf.

[33] Singh, J.S., V.C., Pandey, and D.P., Singh, 2011. Efficient soil microorganisms: A new dimension for sustainable agriculture and environmental development. Agriculture, Ecosystems and Environment, 140(3-4), 339-353. https://doi.org/10.1016/j.agee.2011.01.017.

[34] Stewart, W. M., and T.L., Roberts, 2012. Food Security and the Role of Fertilizer in supporting it, Procedia Engineering journal, 46, 76-82. https://doi.org/10.1016/j.proeng.2012.09.448.

[35] Thome, K, Michael D. ,S, Kamron Daugherty, N, Rada, C Christensen, and Birgit Meade. International Food Security Assessment, 2019-2029.2019. GFA-30, U.S. Department of Agriculture, Economic Research Service.

[36] Thomson, A., \& Metz, M. (1998). Implications of Economic Policy for Food Security: A Training Manual. Food and Agriculture Organization of the United Nations.

[37] Uchenna, N., A., Kalu, 2015. The Impact of Statutory Money Supply Management and Commercial Bank Loans and Advances ( Cbla ) on Economic Growth : An Empirical Evidence in Nigeria. Arabian Journal of Business and Management Review, 3(5), 1-18. http://doi.org/10.12816/0014511.

[38] UN (United Nations) 2015. Transforming Our World: The 2030 Agenda for Sustainable Development. United Nations General Assembly; Seventieth Session. September 18, 2015; New York. Available at: https://www.un.org/en/development/desa/population/migration/generalassembly/docs/globalcompact/A _RES_70_1_E.pdf.

[39] V., Gabor, 2017. A fenntartható mezőgazdaság indikátorrendszerének kialakítása az Európai Unió tagországaira vonatkozóan. Hungarian Central Statistical Office series, ISBN 978-963-235-496-5. Available at: http://www.ksh.hu/docs/hun/xftp/idoszaki/pdf/muhelytanulmanyok10.pdf.

[40] Velten, S., J., Leventon, N., Jager, and J., Newig, 2015. What Is Sustainable Agriculture? A Systematic Review. Sustainability Journal, 7(6), 7833-7865. https://doi.org/10.3390/su7067833

[41] WMO (World Meterological Organization), 2004. Contribution from members on operational applications in agrometerology and from discussants of the papers presented at the international workshop: "reducing vulnerability of agriculture and forestry to climate variablity and climate change. WMO/TD No. $1213 \quad$ Geneva, Switzerland. Available at: http://www.wamis.org/agm/pubs/CAGMRep/CAGM94.pdf.

[42] Wörner, B., S., Krall, 2012. What is sustainable agriculture?. Published by Deutsche Gesellschaft für Internationale Zusammenarbeit (GIZ) GmbH, Available at: file:///C:/Users/HP/Downloads/giz_201201_what-is-sustainable-agriculture\%20(4).pdf ; 